\title{
Caste and Higher Education in India
}

The Caste of Merit: Engineering Education in India. By Ajantha Subramanian (Cambridge, Mass., Harvard University Press, 20I9) 374 pp. \$49.95

Since the beginning of the twenty-first century, in the collective imagination of the Western world, the software engineer has become the characteristic figure of contemporary India. Less well known, especially in Europe, is that the elite of these engineers have come from a handful of schools, the Indian Institutes of Technology (IITS), which were created at India's independence. Benefiting from the privileged official status of "Institutes of National Importance," the IITs attracted, in the second half of the twentieth century, the high castes of Indian society who had already entered the engineering profession during the colonial era. The first generations of graduates of these institutes (the IITians) ascribed their personal success in the highly selective entrance examination to merit, not to their caste affiliation, from which they thought themselves detached. However, the certitude with which these IITians achieved this prominence has eroded because of the entry of disadvantaged caste groups, mainly the OBCs (Other Backward Castes), which have been benefiting from quotas since 2006, in accordance with India's positive discrimination policy. How have the high castes adjusted their representation of their excellence in the face of the arrival of these new social groups? How does the democratic nation of India, which recognizes in its constitution the equality of citizens, implement this principle of affirmative action in a structurally unequal caste society?

Roland Lardinois is a Senior Research Fellow-Habilitation à Diriger des Recherches (HDR) at the French National Centre for Scientific Research (CNRS) and a member of the Centre d'Études de l'Inde et de l'Asie du Sud (UMr 8564) at the École des Hautes Études en Sciences Sociales, Paris. He is the author of Scholars and Prophets: Sociology of India from France $19^{\text {th }}-20^{\text {th }}$ Centuries (New Delhi, 20I3); L'invention de l'Inde: Entre ésotérisme et science (Paris, 2007); with the collaboration of Vignesh Ilavarasam, Le secteur des technologies de l'information et de la communication en Inde: Éducation, formation et emploi des informaticiens (Paris, 20I4).

(C) 2020 by the Massachusetts Institute of Technology and The Journal of Interdisciplinary History, Inc., https://doi.org/ro.II62/jinh_a_oI594 
Such are the issues addressed in Subramanian's The Caste of Merit, which focuses less on the engineering profession than on how to occupy a social place in the institutes that train the nation's technological elite. The aim of this book is to study "the role of engineering education, and the IITs in particular, in producing newly consolidated forms of upper-caste affiliation. The leverage of merit ... must be seen as an expression of upper-caste identitarianism that attempts to forestall progress towards a more egalitarian society and derive its legitimacy from a larger global politics of ascription" (3).

The Caste of Merit also addresses the broader issue of inequality in schooling and education in colonial and independent India. Many historians-for example, Aparna Basu, Krishna Kumar, or Nita Kumar-have already analyzed the politics of education in colonial India, focusing either on specific segments of the population or on the links between the growth of education and the national movement. ${ }^{1}$ More recently, Chaudhary, an economic historian, has renewed the approach in conducting a quantitative survey on education and social divisions at the district level in colonial India. But The Caste of Merit is the first book that deals specifically with professional education, focusing on IITs. $^{2}$

Subramanian conducted her research at the IIT Madras, established in I959 in Tamil Nadu, a state with a strong non-Brahmin movement led by economically and politically powerful landed castes since the end of the nineteenth century-a wise research choice for those interested in the relations between the high caste elites and the lower caste groups. ${ }^{3}$ Drawing her theoretical tools from the general sociology of Bourdieu, Subramanian's methodology is mainly qualitative. ${ }^{4}$ Her data include a combination of personal interviews with alumni of IIT Madras and participant observations, but she expanded her investigation into the United States where

I See Aparna Basu, The Growth of Education and Political Development in India, 1898-1920 (New York, I974); Krishna Kumar, Politics of Education in Colonial India (New York, 20I4; orig. pub. as Political Agenda of Education [Thousand Oaks, I99I]); Nita Kumar, The Politics of Gender, Community, and Modernity: Essays on Education in India (New York, 2007).

2 See Latika Chaudhary, "Essays on Education and Social Divisions in Colonial India," Journal of Economic History, LXVII (2007), 500-503.

3 This movement takes its name from the "Non-Brahmin manifesto," which was published in I9I6 by an association whose members, belonging to the non-Brahmin elites of the Madras presidency, denounced the hegemony of the Brahmins in South India.

4 See Pierre Bourdieu and Jean-Claude Passeron, Reproduction in Education, Society and Culture (London, I977); Bourdieu (trans. Peter Collier), Homo Academicus (Stanford, I990). 
she conducted interviews with IITians holding prominent positions in the information and communications technology (ICT) sector. She complemented these investigations with materials from the Tamil Nadu State Archives. Given its dual historical and sociological perspective, and the strength of its findings about the social reproduction of elites in contemporary India, Subramanian's ambitious work opens a methodological debate.

The first three chapters deal with the history of technical vocational education in the colonial period and the establishment of the first IITs, in particular IIT Madras. Subramanian's argument is that the structure of the technical education established there replicated the divisions of caste society that the British administrators had created according to the census categories. In the mid-nineteenth century, the growing importance of civil-engineering works led the British to set up Public Work Departments (PWDS), which required qualified technical personnel. But the colonial administration and the Indian elites did not always agree about the type of education to pursue. Those in favor of practical on-the-job (shop-floor) training, as in Britain, opposed those who preferred a university-type specialized education (Chapter I).

In India, the British had to confront a division of labor between castes that attached different values to work. Brahmins-usually associated with knowledge and intellectual activities, as well as a denigration of manual labor as religiously inferior-were not likely candidates for the engineering profession, compared, for example, to students from the lower craftsmen's castes.

The proponents of higher technical education prevailed, thus diverging from the British model. By the I 850 , the British had created an engineering college in each of the presidencies that they administered in an attempt to attract the high castes who were then moving toward arts colleges. To promote technical education, the colonial administration leaned toward theoretical knowledge, especially mathematics, rather than practical learning. Students who graduated from these colleges with an engineering degree could be recruited into the PWDs, thus assured of a stable occupation. Three conditions - higher education, theoretical disciplines, and service to the state-explain why the Brahmins, in the Madras presidency, entered the engineering profession early and often. At the same time, the British opened industrial schools to provide practical training for an industrial workforce drawn from the artisan castes. These two 
streams of technical education reproduced the social division of labor between castes and, "on the whole, the two tracks ... diverged but without significant development to either" (57).

MERITOCRACY AND PRIVILEgE In the I95Os, the leaders of the Congress Party created the Indian Institutes of Technology as part of an economic strategy to train a technological elite to implement its ambitious development policy (Chapter 2). These leaders found in the United States-particularly, the Massachusetts Institute of Technology, which had welcomed Indian students since the end of the nineteenth century - their "most desirable model" to achieve this postcolonial goal (69). ${ }^{5}$ Within a decade, five IITs had opened throughout the country: IIT Kharagpur (West Bengal) I95 I, IIT Bombay (Maharashtra) I958, IIT Madras (Tamil Nadu) I959, IIT Kanpur (Uttar Pradesh) I960, and IIT Delhi I96I. From their inception, these schools were celebrated for preparing the technological elite to serve the developmentalist policies of independent India. According to Prime Minister Jawaharlal Nehru, the IITians embodied "the Brahmanic spirit of service" of the young nation (75).

The introduction of higher technical education in the Madras presidency attracted criticism from both the colonial administration and the Indian elites (Chapter 3). Although colonial officials tried to grant the artisan castes access to higher technical education, Subramanian shows that the administration largely promoted the high castes. The non-Brahmin movement that developed from the late I9IOs onward, later turning into Dravidian regional nationalism, crystallized grievances against this policy. The Shudra castes (the fourth varna of the Brahminical classification of Hindu society) railed against the "intellectual" versus "manual" value system of the high castes. $^{6}$

Subramanian highlights the ideological and political polarization of Tamil society in the I920s and I930s around the antagonistic "Brahmin" and "non-Brahmin" blocs. The non-Brahmins challenged the hegemonic position of the Brahmins from a religious,

5 See Ross Bassett, The Technological Indian (Harvard, 2016).

6 In classical Hinduism, people are divided into four varna, or orders-Brahmins, Kshatriyas, Vaisyas, and Shudras, who are hierarchically ordered according to their function, respectively, as priests, kings, merchants, and the ordinary people who have to serve them. The Untouchables, now the Dalits (in sanskrit meaning "broken" or "scattered," now known as the "oppressed" in contemporary India), are not classified within these four varna. 
cultural, and social point of view. They also denounced the high castes for presenting themselves as the natural bearers of knowledge and intelligence and the peasant and artisan castes as the menials beneath them. By the beginning of I920s, the regional government had already established quotas in public education for the benefit of these non-Brahmin castes, which were largely disadvantaged, particularly in terms of education.

The next three chapters focus on the struggles of different social groups for legitimacy within IIT Madras since the I960s. Subramanian reveals a tension between two modes of status acquisition in contemporary India- "ascription," linked to caste or class of origin, and "achievement," which, though ostensibly associated with the merit, actually derived less from personal qualifications than from the collective resources of a social group. Subramanian draws a group portrait of the first generations of IIT Madras graduates (Chapter 4). The alumni of the I960s were mostly from English-speaking, urban, high-caste families, many of them Brahmins (their fathers often university graduates, whose rapid upward social mobility had earned them employment opportunities in the government services of Madras or Delhi). Their secondary education had been in the best English-language schools affiliated with the Central Board of Secondary Education, where the programs prepared them for the entrance examination to the IITs (other secondary schools, which depended on the boards of the regional states, taught a more elementary syllabus in Indian languages). After obtaining a Bachelor of Technology, these privileged graduates joined the central government to develop the industrial infrastructure. They felt that they had transcended regional and caste divisions to form a national elite detached from their traditional affiliations: "I 960 IITians almost uniformly claim a form of post-caste subjectivity" (I I 8).

According to Subramanian, however, their chosen narrative conceals the social mechanics of the Joint Entrance Examination (JEE) at IIT Madras, which defines the selection process for the technological elite (Chapter 5). The British had introduced the social technology of the examination in India as early as I 855 to recruit members of the upper civil service; it became widespread after independence, notably to regulate access to higher vocational education. The first competitive examination for entry into IITs took place in I96I. In 20I3, 468,000 candidates competed for approximately I0,000 places - a success rate of around 2 percent. Borrowing Bourdieu's 
framework, particularly the concept of capital, Subramanian shows how this examination transformed the social hierarchy of the candidates into a legitimate school hierarchy that concealed the extent to which social origin, caste, or class were causal factors for success, thus reproducing the inequalities between social groups. This is the point at which the questionable notion of merit arises, both in the discourse of those directly involved as well as in Subramanian's analysis.

The Tamil Brahmins elaborated their notion of merit in line with the feelings of victimization to which the non-Brahmin movement in the first half of the twentieth century was reacting. They originally defended their intellectual capacities as inherited from their caste to justify their standing but then moved to a class-based meritocracy to justify their entry into higher professions. In Subramanian's words, "class has become a critical alibi that makes possible a reconciliation between caste inheritances and the democratic principle of meritocracy" (IO6). The mechanics of the examination complete this operation by transforming "caste capital" into educational privilege: "Ascription was reconciled with achievement by delinking caste from capital" (I67).

Affirmative Action and the IITS The introduction of quotas for the three hitherto under-represented caste groups, however, challenged the prominent position of high castes in the IITs. The process took place in two stages. First, in I973, I 5 percent of the seats went to the Scheduled Castes (SCs) - formerly the Untouchables and presently known as Dalits - and 7.5 percent to the Scheduled Tribes (STS). Yet the entry of these two groups did not change the elitist feeling of the IITians; the respective shares of the SCS and STS at IIT Madras remained well below these thresholds for a long time. In 2006, however, after twenty years of political struggle, the central government imposed a quota of 27 percent for the Other Backward Castes (OBCs), a group of "intermediate castes" between scs and "upper castes" (I07). At this point, 49.5 percent of seats are theoretically reserved for these three groups. The remaining 50.5 percent of seats constitute the General Category (GC) — also known as the Open Category (OC), because students belonging to SCS, STS and OBCs, depending on their marks in the entrance examination, may apply for one of its seats rather than for one in a quota category. The GC is not the exclusive domain of the high-caste groups excluded from the quotas.

The oBCs did not miss their opportunity; they flocked in large numbers to the coaching centers, often run by IITians, that prepare 
candidates for entrance examinations to engineering colleges. Nonetheless, since the I950s, particularly in Tamil Nadu, the high castes have fought the "positive discrimination" policy with a profusion of legal appeals claiming discrimination (Chapter 6). As a result, the high castes have had to adjust the way in which they represent their social and educational position. Until the beginning of the twentyfirst century, the ideology of merit promoted by high-caste IITians complemented their identification with the nation-state to overcome regional, linguistic, and caste divides: "The claim to meritocracy was expressed in universalistic terms" (256). But the rise of the OBCs changed the self-image of the high castes "from universalistic to a more identitarian expression of upper caste identity" (258). Indeed, high castes now associate the notion of merit with state categories to separate, and order, groups into two blocks. From their point of view, the Open Category refers to true deserving students who owe nothing of their academic success to their caste, whereas the Reserved Category carries students who have been granted a seat in IITs solely because of their caste. As Subramanian writes, high castes have developed "a consolidated form of upper casteness irreducible to any one endogamous grouping" (256). Tamil Brahmins, however, never appear to have dissociated their sense of merit from their caste belonging.

Brand IIT India's integration into the market economy from the I980s onward granted IITians new opportunities for transnational migration. About one-third of them migrated to the United States to pursue their studies and often to work thereafter, notably in ICT. In fact, the "Brand IIT" originated in the United States, its most visible form being the network of IIT alumni, "The Indus Entrepreneurs," organized at the end of the I990s (Chapter 7). In her innovative discussion of this phenomenon, which is well-informed by interviews with leading practitioners, notably Silicon Valley entrepreneurs, Subramanian shows "Brand IIT" as the invention of Indian engineers in an attempt to remove themselves ethnically from the racist line of fire that African-American communities endure. Interestingly, many of these IITians are from IIT Bombay rather than IIT Madras and come from upper middle-class families and castes of good standing, though many of them are not Brahmins.

In her concluding chapter, Subramanian covers the struggles of students from the lower castes against "the ideology of meritocracy" that helps to consolidate the hegemonic position of the upper castes 
(3 I 5). The "subalterns," whose acquired rights are under attack by the Bharatiya Janata Party-a right-wing Hindu nationalist party in power at Delhi since 20I4-are, according to Subramanian, the only groups that defend the democratic principles of the "common good" and "universal equality" (322).

MERIT, TALENT, AND CASTE The Caste of Merit is unprecedented in three respects: (I) by its subject matter, since the history of higher technical education in India, especially the history of the IITs, is a relatively new field of research; (2) by its use of social anthropology, comprising interviews, oral history, and archives; and (3), by viewing the history of an elite group through the prism of the inequalities of the caste system that structures Indian society. Subramanian's historical-anthropological approach, however, raises methodological questions when it moves from anthropological observation to sociological reasoning to reach its general conclusions supporting the emancipatory cause of subordinate groups.

The book's parsimonious use of terms in Indian languages is a rare practice in India's social anthropology. Although it may reflect Subramanian's attempt to erase any hint of exoticism or "orientalism," the implicit assumption of this choice is that social-science concepts are universal and as applicable, without critical examination, to Indian society as they are to American or French society. Consider the two notions of merit and caste in the title of the book. Subramanian's discussion of merit is based on Carson's work, which likens the concept to the notion of "virtues and talents" in the republican discourse of the philosophers of the European Enlightenment (I 7-2 I). ${ }^{7}$ According to Subramanian, merit serves as "a key alibi for the perpetuation of social hierarchy after the advent of republican democracy" (I 8). Although she wants to transpose this point of view to the Indian case, the two notions of merit and talent require a sociological discussion that is absent from Subramanian's book. Merit accrues to the performer of an action, as reward or punishment, according to the moral value accorded to the result of the action. But for positive or negative merit to be meaningful, the performer of the action must be a bearer of proper qualities, capacities, or "talents" and must be

7 John Carson, The Measure of Merit: Talents, Intelligence and Inequality in the French and American Republics, 1750-1940 (Princeton, 2006), discusses merit and talent in a technical sense without much interest in their theological grounding. 
endowed with relative agency, two elements that causally account for an action's results and ultimately lead to the performer's merit or demerit. But societies' views of merit vary by time as well as by the religious cultures that shaped them.

In the European societies to which Subramanian refers, the notions of talent and merit have a theological charge that Subramanian does not take into account. Talent, the Greek origin of which denotes a measure of weight, takes its moral meaning from the Parable of the Talents of the Gospel according to Matthew, whereas merit refers to the ideas about good deeds and salvation associated with Thomas Aquinas. ${ }^{8}$ Even in a modern secular context, that is to say, in a regime of democratic equality, is it certain that merit signifies the same thing in the United States, a predominantly Protestant society; in France, a predominantly Catholic one; and in India, where Hinduism as a way of life is consubstantial with the caste system? In the course of Subramanian's interviews with people of different castes, at least some of her respondents, even those who were engineers, must have identified with a culture of merit that had Hindu overtones. Surely merit requires contextual questioning before it can be made a universal secular notion.

Caste The word caste throughout the book refers to social groups whose differences Subramanian sometimes points out but rarely takes into account, despite a section devoted to anthropological and historical debates on the subject $(8-\mathrm{I} 3)$. This term, with which the sociology of India cannot dispense, has at least five different meanings in the book: First, it refers to specific groups, in the anthropological sense of the term, such as Brahmins, specified according to their geographical origin (Tamil, Maratha, or Bengali), or to landed castes, such as the Kamma and the Reddy of Andhra Pradesh (in South India). But the term also refers to the state groups that benefit from the affirmative-action policy, who together oppose those excluded from the reservation policy but not from the General Category, which includes Brahmins. This last state category is often equated with the "upper castes," which Subramanian distinguishes en bloc to the "lower castes" or the "subalterns," without clarifying

8 See Pierre-Michel Menger, "Qu'est-ce que le talent? Éléments de physique sociale des différences et des inégalité," Annuaire du Collège de France 2016-2017: Résumés des cours et travaux (Paris, 2019), 483-502; idem (ed.), Le talent en débat (Paris, 2018); Yves Michaud, Qu'est-ce que le mérite (Paris, 2009). 
whether she intends this designation to include the SCS, the STs, and the OBCs, or the SCs and the STs, or simply the SCs (the Dalits).

Occasionally, in a third use of caste, Subramanian refers to the OBCs as Shudra, though she never relates the "upper castes," which dominate the General Category, to the Kshatriyas and the Vaishyas, the other two higher varnas. The fourth sense considers caste much more broadly, associating it with a large family of social terms, such as class, race, ethnic group, "and other structures of social stratification" $(328$, n. 23). Finally, in the title of the book, the term assumes a metaphorical guise, a descriptive element coupled with a negative moral judgment, which allows a denunciation to be made from an ethico-political point of view. ${ }^{9}$

These remarks will seem trivial to specialists of India for whom these different uses of the word caste are common. Nevertheless, it is the sociologist's task to explicate such sociological indeterminacy. At times, Subramanian reduces caste to social stratification - not unlike the way in which secular society treats merit-by disconnecting it from the socioreligious structure of Hinduism. This approach makes it difficult to understand the varna classes from a scriptural point of view, given Subramanian's and others' designation of the OBCs as Shudras. Secondly, how can the various groups subsumed under the heading of caste, with their different epistemic statuses and vast numerical sizes, conform to sociological analysis when they are so indistinct? The incongruity between the book's rejection of the colonial reification of castes and its subsequent reification of the SC, ST, and OBC categories begs a question about the precise social structure within which these categories operate.

Subramanian fails to notice that the classification of the groups that benefit from the reservation policy largely reproduces, in both structure and spirit, the quadripartition of the Hindu society by varna, thereby attesting to the persistence of a decidedly Hindu pattern. ${ }^{10}$ By taking up this modern sociolegal classification of the Hindu world in a noncritical way, Subramanian makes non-Hindu

9 For caste in the United States, which is never used as a simple descriptive term, see Daniel Immerwahr, "Caste or Colony? Indianizing Race in the United States," Modern Intellectual History, IV (2007), 275-30I; for an example of the term caste used in political denunciation, Laurent Mauduit, La caste: Enquête sur cette haute fonction publique qui a pris le pouvoir (Paris, 2019).

Io See Lardinois, "Caste: Concept, Words and Things," in Surinder Jodhka and Jules Naudet (eds.), Handbook on Caste (Delhi, forthcoming). 
religious minorities disappear from her analysis, especially Muslims, who are excluded, a priori, from reservation policies. Only a few Muslim surnames (assuming that surnames alone can identify a religious affiliation to Islam) receive mention in The Caste of Merit, as though the place of this minority within IIT Madras was scarcely worth questioning. Do Indian Muslims, even if they are Tamils, have the same representation of merit as Tamil Brahmins?

A second caveat regarding the book concerns the lack of quantitative data. Although Subramanian's qualitative approach is not without value, she makes no case for the representativeness of the population that she studies. The annual reports of IIT Madras provide data that would have helped to situate the graduates. The twenty or so interviews that Subramanian conducted with alumni of the I960s represent only I percent of the approximately 2,000 graduates for the first eight promotions from 1964 to 1970 alone. ${ }^{11}$ Was its social and cultural homogeneity reducible to a Brahmin milieu? In the first two promotions of I20 students each, in I959/60 and I960/I, the three groups of SCS, STs, and Backward Castes represented 20 percent of the students admitted. ${ }^{12}$ However, this proportion declined to about 8 percent after the first JEE examination in I96I; almost half a century later, in 2008 , the SCs and STs together accounted for I 5 percent of the total students. ${ }^{13}$ How can Subramanian explain this evolution? Who were the early SCs and STS, and how did the share of Backward Castes evolve at IIT Madras before quotas made the OBC category statistically visible from the late 2000 onward?

BOURDIEU AND SUBRAMANIAN Bourdieu's sociology, which places domination at the center of its theoretical framework, can provide heuristic tools for analyzing the history of the caste system; power relations, which are absent to some extent in scriptural Brahmanical Hinduism, structure the social and political struggles of contemporary India, most noticeably in education. ${ }^{14}$ Bourdieu and Passeron's study of competitive examinations applies well to IITs. ${ }^{15}$ Yet, a proper understanding of the IITs must take into account, as The Caste of Merit

I I IIT Madras Annual Report 1970-71 (Annexure E, Pattern of Graduation I964-7I), 24.

I2 IIT Madras Annual Report 1959-6o (Admissions, 4); Annual Report 1960-61 (Admissions, 5).

I 3 IIT Madras Annual Report 2008-og (OBC/SC/ST Students under Fresh Admission), 45-46.

I4 See Lardinois, Scholars and Prophets: Sociology of India from France $19^{\text {th }}-20^{\text {th }}$ Centuries (New Delhi, 20I3).

I5 Bourdieu and Passeron, Reproduction in Education Society and Culture. 
does not, that these institutions fall within a field of higher technical education that, despite its complex structure, is unified at the panIndian level by a competitive examination system. ${ }^{16}$ To qualify for the entrance examination to the IITs - the JEE-Advanced (not simply the JEE) - candidates must first pass the JEE-Main, an examination that distributes students according to rank in all the engineering colleges of the public sector, other than the IITs. ${ }^{17}$ The selection of the IITs therefore operates more at the level of the Bachelor of Technology (втесh) that these institutes deliver than at the level of the Master of Technology (MTech), which is open to holders of a Bachelor of Engineering delivered by other colleges when they have passed the requisite examination.

Capital and Social Space Determination of the IITian grade"who is a 'true' IITian"? (25) - is disputed not only between groups according to their mode of access (the quota system or otherwise) but also between those who have access to IITs at the BTech or MTech levels. Moreover, the fivefold increase in the number of IITs since 2016 (now numbering twenty-three) does not bestow the same standing on all IITs. The unmatched glory of the first five, uncontested for four decades, links these elevated IITs to an ancient social space (in Bourdieu's sense; see below). The production of the "Brand IIT" (see above) by the alumni of these historical IITs helps to consolidate the position of these older IITs in relation to the more recent ones.

Notwithstanding the efficiency of Bourdieu's concept of capital, Subramanian's simplified use of it hinders her analysis. First, she relates capital most often to the educational capital of Brahmins and only occasionally to other forms, such as land. But Subramanian does not construe the concept in a systematic, analytical way to describe the different types of resources available to the people that she studies and to castes in general. In fact, she mainly considers it in toto (all forms combined), frequently employing it to describe caste as a collective entity, as in the expression "caste capital." As a result,

I6 British India had about Io engineering colleges around I900, about Ioo in I960, a little more than 500 colleges at the end of the I990s, but nearly 3,500 at the beginning of 20Io. See Technical Education in Independent India 1947-1997: A Compendium to the $50^{\text {th }}$ Anniversary of Independence (New Delhi, I999); for the following years, see data at https://www.aicte-india.org/. Regarding the field of engineering education in India, see Lardinois, "L'espace social des écoles d'ingénieurs en Inde: Entre l'État et le marché," in Antoine Derouet and Simon Paye (eds.), Les ingénieurs, unité, expansion, fragmentation (XIX et $\mathrm{XX}^{e}$ siècles) (Paris, 20I8), 2 I 5-239.

I7 Not included in this discussion are the prestigious private engineering colleges recruitment to which is totally independent of the JEE examination. 
Brahmins often appear as the only holders of a "caste capital"; other castes, defined negatively, are utterly devoid of it. Hence, Subramanian neglects the double analytical dimension of capital-its volume or total amount and its composition, "the structure of the distribution of the different types of capital at a given moment in time.", 18

Employing this generic double dimension of capital, Bourdieu empirically constructs the notion of space or field, especially social space, which is always multidimensional. ${ }^{19}$ Subramanian's neglect of the overall volume of capital and the distribution of its different forms at a given moment for all groups, however, leaves social space out of the analysis entirely. More precisely, by unilaterally considering the volume of capital, rarely decomposed into its different forms, she reduces social structure to a simple stratification, a stacking of classes or castes ranked according to the global volume of their resources. This outlook implicitly reproduces the traditional hierarchy of the caste, or varna, system, with the "upper castes" at the top and the "low castes" or "subalterns" (SCS, STs, and OBCS) at the bottom. ${ }^{20}$ Subramanian presents the relationship between "caste" and "capital" in a wooden and mechanical way that makes it difficult to account for the ability of people to interact in the social world at all.

Presuppositions and Flaws Subramanian's use of Bourdieuan sociology embodies presuppositions that raise several questions. The Caste of Merit is an instance of critical sociology in the sense that it purports to describe empirically the functioning of a social orderan educational system's production of elite engineers - while also rendering judgments about the social world that underlies it. However, these two types of assessment are based on two types of discourse- on the one hand, social-scientific observation and, on the other, an ethical/political critique of actions in a social context. The factual approach requires an axiological neutrality with regard to ethical/political values. It occurs at an epistemic level, not at the level

I 8 Bourdieu, "The Forms of Capital," in John G. Richardson (ed.), Handbook of Theory and Research for the Sociology of Education (Westport, I986), 24I-242.

I9 See Bourdieu, "The Social Space and the Genesis of Groups," Theory and Society, XIV (I985), 723-744; idem, The State Nobility: Elite Schools in the Field of Power (Stanford, I998).

20 For a tentative construction of the Indian social space using the tools of Bourdieu's sociology, see Mathieu Ferry, Jules Naudet, and Olivier Roueff, "Seeking the Indian Social Space," South Asia Multidisciplinary Academic Journal, available at http://journals.openedition. $\mathrm{org} / \mathrm{samaj} / 4462$ (accessed March 29, 2018). 
of action in the world. The absence of a clear distinction between the two modes of discourse creates problems for Subramanian's analysis.

The study of the processes by which the social inequalities of caste transferred to school hierarchies-for some people engendering a sense of personal merit and for others, a sense of exclusion-is a fact-finding matter. However, ideas about the deleterious effect of these processes on social equality necessarily hang on principles external to the object of study. In her concluding chapter, Subramanian mentions two major principles that operate in a democratic regime- "universal equality" and "distributive justice" (322, 32 I). Indeed, we might wish to argue, after describing the facts per se, that the functioning of IITs, contradicts the ethics of equality and justice. First, however, we would have to explain, from a sociological point of view, how these two general principles figure into a host of complex debates - an issue that Subramanian overlooks - and then to justify sociology's role in promoting emancipation, which implicitly guides Subramanian's analyses. ${ }^{21}$ Furthermore, reaching agreement about the various ways of linking sociological analysis, critical effect, and political action is another matter altogether.

In the absence of a clear statement of the presuppositions within her analytical framework, Subramanian engages in an asymmetrical treatment of the groups studied, thus blurring the sociological understanding of the observed facts. For example, she denounces highercaste claims to merit as an ideology, a travesty of privilege, whereas she supports lower-caste claims to rights as wholly legitimate. Yet, in the sentence that closes the book, Subramanian re-introduces the notion of merit as a positive value by positing meritocracy as an ideal norm (value judgment). Thus, she questions the meritocratic principle not because it is an illusion of those who defend it but because it does not apply equally to subordinate groups: "Although meritocracy as a principle continues to animate calls for equalization, the divergence between its ideal meaning and its social life should call into question the assumption that meritocracy is indeed a leveler of opportunity" (323).

2I See for example, Michael Walzer, Spheres of Justice: A Defense of Pluralism and Equality (New York, 1983) (for the religious grounding of talent and merit, 243-248); Amartya Sen, Equality of What? (Stanford, I979); idem, "Merit and Justice," in Kenneth Arrow, Samuel Bowles, and Steven N. Durlauf (eds.), Meritocracy and Economic Inequality (Princeton, 2000), 5-I6. 
To overcome this contradictory viewpoint, the sociological approach must consider all values equally without judgment. The facts as presented in The Caste of Merit attest to complex and conflicting value systems for which proponents offer various justifications. The role of the sociologist is to objectify these value systems and to understand the reasons for them, not to denounce them. The opposition between "claims to merit" and "claims to right" illustrates the asymmetry of Subramanian's analysis, but these two registers are supposed to apply to everyone. Why exclude subalterns from the right to merit? Subramanian shows that all of her subjects believe that they have rights, whether subalterns or Brahmins. These rights, however, refer to different legal principles (fundamental rights vs. rights of disadvantaged groups), and their validity varies according to hierarchical jurisdiction (Indian Union or regional states). ${ }^{22}$

From the perspective of pragmatic sociology, the legal disputes about the interpretation of these rights, the outcomes of which varied historically according to the power relations between groups in the political field, can serve as "reality tests" (épreuves) that permit us to identify the main registers in which particular values make sense. But even disputes that manage to find legal closure at a given moment can persist in the social world because the registers of justification are often contradictory and incompatible. The constitution of India provides the resources for social activists to pursue these disputes, whether through democratic values of equality and justice or through conflicting values inherited from the ancient caste system. ${ }^{23}$

During the colonial era, Indian elites-landed elites and the traditional literate groups, notably the Brahmins - were the chief beneficiaries of English education. Furthermore, Chaudhary underlines that "many of these same elites actively blocked schemes for public expansion of primary schooling" as a way to capture the benefits of English education on a larger scale. What is at issue in this review essay is not the empirical evidence regarding the asymmetrical access to higher education in colonial and independent India but the theoretical

22 For further analyses of engagement, neutrality, and value, see Nathalie Heinich, "Pour une neutralité engagée," Questions de communication (2002), available at http://questionsdecommunication. revues.org/7084; doi: I0.4000/ (accessed October I, 20I6); idem, Des valeurs: Une approche sociologique (Paris, 2017).

23 See Luc Boltanski and Laurent Thévenot, On Justification: Economies of Worth (Princeton, 2006); Boltanski, On Critique: A Sociology of Emancipation (New York, 20 I I). 
framework required to explain and generalize behind the factual evidence. ${ }^{24}$

The analyses of scholars who do not differentiate between epistemic virtues and ethico-political values are prone to the same contradictions as those of the populations under study. In this regard, The Caste of Merit falls prey to difficulties inherent in the practice of sociology. Subramanian's book will interest historians, anthropologists, and sociologists of modern and contemporary India, as well as social scientists who wonder about the empirical and theoretical premises that scholars must satisfy before they promote social causes beyond the conveying of objective information. ${ }^{25}$

24 Chaudhary, "Caste, Colonialism and Schooling: Education in British India," in idem et al. (eds.), A New Economic History of Colonial India (Oxford, 2016), I6I-I78.

25 For an example of the same contradiction - a critique of the "myth of merit" and a call for a "redefinition of merit," expressed from an explicitly subaltern view point, see Kancha Ilaiah, "Merit of Reservation," Economic and Political Weekly, XLI (2006), 2447-2449. 